\title{
Anticonvulsant evaluation of 2-pyrazolines carrying naphthyl moiety: An insight into synthesis and molecular docking study
}

\author{
Birjees Nusrat ${ }^{1}$, Nadeem Siddiqui*,1, Meeta Sahu ${ }^{1}$, Mohd. Javed Naim¹, Mohammad ShaharYar \\ Ruhi Ali ${ }^{1}$, Ozair Alam ${ }^{1}$
}

${ }^{1}$ Department of Pharmaceutical Chemistry, Faculty of Pharmacy, Jamia Hamdard, Hamdard Nagar, New Delhi, India

\begin{abstract}
A series of $N$-substituted-3-(napthalen-2-yl)-5-substituted phenyl-4,5-dihydropyrazole-1-carbothioamide derivatives (4a-n) were synthesized with the view of structural requirements of pharmacophore for potential anticonvulsant agents. The synthesized compounds were assayed intraperitoneally (i.p.) and subcutaneously (s.c.) in mice against seizures induced by MES and scPTZ methods, respectively. Neurologic deficit was evaluated by rotarod method. Among the tested compounds, $\mathbf{4 g}, \mathbf{4 i}, \mathbf{4 j}$ and $\mathbf{4 n}$ emerged as the most active molecule in the MES model at a dose of $30 \mathrm{mg} / \mathrm{kg}$ at $0.5 \mathrm{~h}$ comparable to standardscarbamazepine and phenytoin. In the scPTZ test,4e and $\mathbf{4 l}$ were found to be most active compounds at the lowest dose of $30 \mathrm{mg} / \mathrm{kg}$ at $0.5 \mathrm{~h}$, in the management of the convulsive disorder. Molecular docking studies of the titled compounds were also donewith 3D crystal structure of human cytosolic branched chain amino transferase (hBCATc) enzyme and compound $\mathbf{4 e}$ was found to have five hydrogen bond interactions with the most important active site residues.In neurotoxicity studies, except compounds $\mathbf{4 b}, \mathbf{4 c}, \mathbf{4 h}$ and $\mathbf{4 k}$, rest of the compounds showed no sign of toxicity.
\end{abstract}

Keywords: Pyrazolines. Anticonvulsants. Molecular docking. Neurotoxicity.

\section{INTRODUCTION}

Epilepsy is a collective term for brain function disorders that are characterized by the periodic and unpredictable occurrence of seizures. Epilepsies are common and frequently devastating, affecting around $1-2 \%$ of the world population (Thakur et al., 2011). With available marketed antiepileptic drugs (AEDs) complete control of seizures is not achieved till date and also these drugs are associated with a wide range of side effects (Desaubry et al., 1995).

Recent AEDs like lamotrigine, tiagabine, felbamate, pregabalin, stiripentol and topiramate are effective toward only $60-80 \%$ of patients but these drugs are also associated with undesirable side effects, such as headache, nausea, anorexia, ataxia, hepatotoxicity, drowsiness, gastrointestinal disturbance, gingival hyperplasia and hirsutism (Malik, Bahare, Khan, 2013). Therefore, valproic acid and carbamazepine, first generation drugs are

\footnotetext{
*Correspondence: N. Siddiqui. Department of Pharmaceutical Chemistry, Schoo of Pharmaceutical Education and Research, Jamia Hamdard, Hamdard Nagar, New Delhi, India. Tel: +91 1126059688 x 5307; Fax: +91 1126059688 x 5307. E-mail: nadeems_03@rediffmail.com; nadeems_03@yahoo.co.in iD
}

still widely used. Because of limitations with conventional AEDs, the need for developing newer agents for epilepsies is need of the millennium.Every year March 26 is celebrated as Purple Day to raise awareness of epilepsy.

Pyrazoles and their reduced forms, pyrazolines, are nitrogen-containing heterocyclic compounds (Beyhan et al., 2017). Among all, 2-pyrazolines (4,5-dihydropyrazole) continue to be the most promising structural unit for various synthetic molecules in respect of the highly potential pharmacological profile (Motyan et al., 2016). Derivatives containing the 2-pyrazoline moiety have been reported to have diverse biological activities such as antimalarial, antimicrobial, antituberculosis, antioxidant, anti-inflammatory, anticancer, anti-microbial, anti-parasitary, antidepressive and anticonvulsant properties (Karad et al., 2016). Many researchers have reported various routes for their synthesis; the most common one is by condensation of $\alpha, \beta$-unsaturated carbonyl compound with hydrazine derivatives (Miguel et al., 2016).

A pharmacophoric model essential for good anticonvulsant property was proposed (Dimmock et al., 1995; Dimmock, Vashishtha, Stables, 2000). According 
to this model, an anticonvulsant compound should have at least one aryl binding site with the hydrophobic group, electron donor atoms, hydrogen bonding domain and hydrogen binding site in it.

Docking studies have been carried out in order to investigate the interactions (ALA 314, THR 313, LYS 202, TYR 141, ARG 143 \& PHE 75) at the molecular level that govern the recognition and binding of synthesized ligands to the human cytosolic branched chain amino transferase (hBCATc).The hBCATc helps in catalyzing the transfer of an amino group from branched chain amino acids to $\alpha$-ketoglutarate and leads to the synthesis of glutamate in CNS (Hu et al., 2006). The inhibition of this hBCATc in the brain can reduce the release of glutamate during excitation in neuronal tissues. Hence, the inhibition of glutamate release is useful for the treatment of the neurodegenerative disorder such as epilepsy.

We hereby described the synthesis, characterization, dockingstudy and anticonvulsant evaluation of $N$-substituted-3-(napthalen-2-yl)-5-substitutedphenyl4,5-dihydropyrazole-1-carbothioamide derivatives (4a-n) using MES and scPTZ method. Neurotoxicity studies were also done to explore the toxicity.

\section{MATERIAL AND METHODS}

All the chemicals used in the synthesis were procured from E. Merck and SD Fine-Chem Limited. Thin layer chromatography (TLC) was performed on Silica gel 60 F254 TLC aluminum sheets (Merck) using toluene/ ethyl acetate/formic acid (5:4:1) and benzene/acetone (9:1) as a solvent system. The melting points were recorded in open capillaries using Hicon melting point apparatus (Hicon, India) and are uncorrected. FT-IR spectra were recorded in $\mathrm{KBr}$ disks using Shimadzu affinity-1(Model number 8400S). ${ }^{1} \mathrm{H}$ NMR spectra were recorded in $\mathrm{CDCl}_{3}$ on Bruker Avance on $300 \mathrm{MHz}$. Elemental analysis for $\mathrm{CHN}$ was within $\pm 0.4 \%$ of the theoretical values. PTZ was procured from Shrenik Pharma Ltd. (Mumbai). Anhydrous sodium sulfate was used as the drying agent.

\section{Preparation of alkyl and aryl isothiocyanates (1a-d)}

The alkyl and aryl isothiocyanates (1a-d) were prepared as per standard procedure (Furniss et al., 1998).

\section{General synthesis of chalcones (2a-e)}

A mixture of equimolar portions of appropriate aromatic aldehydes $(10 \mathrm{mmol})$ and 2-acetyl naphthalene
(10 mmol) was dissolved in $20 \mathrm{~mL}$ of ethanol and stirred for 30 minutes at $5{ }^{\circ} \mathrm{C}$. To the reaction mixture, $10 \mathrm{~mL}$ of $10 \%$ aqueous solution of sodium hydroxide was slowly added dropwise using a funnel. The mixture was again stirred for $2 \mathrm{~h}$ keeping the temperature below $10^{\circ} \mathrm{C}$ and was kept at room temperature overnight. The resulting precipitates were collected by suction filtration, washed with ice-cold water, dried and recrystallized from absolute ethanol.

\section{General synthesis of pyrazoline derivatives (3a-e)}

The chalcone (2a-e) was dissolved in $20 \mathrm{~mL}$ of ethanol and $98 \%$ of hydrazine monohydrate $(4 \mathrm{~mL})$ was added dropwise with stirring. This mixture was stirred further for 1 hour. The precipitates formed were collected and recrystallized from absolute ethanol to obtain (3a-e).

\section{Synthesis of target compounds (4a-n)}

A mixture of compounds (3a-e, $0.01 \mathrm{~mol})$ and alkyl/aryl isothiocyanates $(0.01 \mathrm{~mol}, \mathbf{1 a - d})$ in $20 \mathrm{~mL}$ of absolute ethanol was refluxed for 4 hours to obtain the product (4a-n). The product obtained was purified and recrystallized from appropriate solvent.

5-(4-Bromophenyl)-N-cyclohexyl-3-(naphthalen-2-yl)4,5-dihydropyrazole-1-carbothio amide (4a)

Sand yellow (amorphous). m.p.: $144-148^{\circ} \mathrm{C}$; IR $\left(\mathrm{KBr}, \mathrm{cm}^{-1}\right): 3461(\mathrm{NH}), 1578(\mathrm{C}=\mathrm{N}), 1342(\mathrm{C}=\mathrm{S}) ;{ }^{1} \mathrm{H}$ NMR $\left(300 \mathrm{MHz}, \mathrm{CDCl}_{3}\right)$ : $\delta$ 7.05-7.91 (m, $\left.11 \mathrm{H}, \mathrm{Ar}-\mathrm{H}\right)$, $4.17\left(\mathrm{dd}, 1 \mathrm{H}, \mathrm{H}_{\mathrm{A}}, \mathrm{J}_{\mathrm{AB}}=17.73 \mathrm{~Hz}, \mathrm{~J}_{\mathrm{AX}}=8.06 \mathrm{~Hz}\right), 4.24$ $\left(\mathrm{dd}, 1 \mathrm{H}, \mathrm{H}_{\mathrm{B}}, \mathrm{J}_{\mathrm{BA}}=17.73, \mathrm{~J}_{\mathrm{BX}}=4.27 \mathrm{~Hz}\right), 4.63(\mathrm{dd}, 1 \mathrm{H}$, $\left.\mathrm{H}_{\mathrm{X}}, \mathrm{J}_{\mathrm{XA}}=8.07 \mathrm{~Hz}, \mathrm{~J}_{\mathrm{XB}}=4.25 \mathrm{~Hz}\right), 9.12\left(\mathrm{~s}, 1 \mathrm{H}, \mathrm{NH}, \mathrm{D}_{2} \mathrm{O}\right.$ exchangeable), 1.35-3.46 (m, $11 \mathrm{H}, \mathrm{CH}_{2}$-cyclohexane); Anal. calcd. for $\mathrm{C}_{26} \mathrm{H}_{26} \mathrm{BrN}_{3} \mathrm{~S}: \mathrm{C}, 63.41 ; \mathrm{H}, 5.32 ; \mathrm{N}, 8.53$; Found: C, 63.45; H, 5.34; N, 8.56\%.

N-cyclohexyl-3-(naphthalen-2-yl)-5-phenyl-4,5-

dihydropyrazole-1-carbothioamide (4b)

Greenish-yellow (crystals).m.p.: $170-173^{\circ} \mathrm{C}$; IR $\left(\mathrm{KBr}, \mathrm{cm}^{-1}\right): 3459(\mathrm{NH}), 1572(\mathrm{C}=\mathrm{N}), 1362(\mathrm{C}=\mathrm{S})$; ${ }^{1} \mathrm{H}$ NMR $\left(300 \mathrm{MHz}, \mathrm{CDCl}_{3}\right): \delta 6.95-7.84(\mathrm{~m}, 12 \mathrm{H}$, Ar- $\mathrm{H}), 4.25\left(\mathrm{dd}, 1 \mathrm{H}, \mathrm{H}_{\mathrm{A}}, \mathrm{J}_{\mathrm{AB}}=17.61 \mathrm{~Hz}, \mathrm{~J}_{\mathrm{AX}}=8.03\right.$ $\mathrm{Hz}), 4.32\left(\mathrm{dd}, 1 \mathrm{H}, \mathrm{H}_{\mathrm{B}}, \mathrm{J}_{\mathrm{BA}}=17.61 \mathrm{~Hz}, \mathrm{~J}_{\mathrm{BX}}=4.25 \mathrm{~Hz}\right)$, $4.65\left(\mathrm{dd}, 1 \mathrm{H}, \mathrm{H}_{\mathrm{X}}, \mathrm{J}_{\mathrm{XA}}=8.05 \mathrm{~Hz}, \mathrm{~J}_{\mathrm{XB}}=4.27 \mathrm{~Hz}\right), 9.24$ (s, 1H, NH, $\mathrm{D}_{2} \mathrm{O}$ exchangeable), 1.38-3.69 (m, 11H, $\mathrm{CH}_{2}$-cyclohexane);Anal. calcd. for $\mathrm{C}_{26} \mathrm{H}_{27} \mathrm{~N}_{3} \mathrm{~S}: \mathrm{C}$, 75.51; H, 6.58; N, 10.16; Found: C, 75.49; H, 6.60; $\mathrm{N}, 10.19 \%$. 
5-(4-Chlorophenyl)-N-cyclohexyl-3-(naphthalen-2-yl)4,5-dihydropyrazole-1-carbothio amide (4c)

Brownish yellow (amorphous). m.p.: $132-134^{\circ} \mathrm{C}$; IR $\left(\mathrm{KBr}, \mathrm{cm}^{-1}\right): 3360(\mathrm{NH}), 1570(\mathrm{C}=\mathrm{N}), 1356(\mathrm{C}=\mathrm{S}) ;{ }^{1} \mathrm{H}$ NMR $\left(300 \mathrm{MHz}, \mathrm{CDCl}_{3}\right)$ : $\delta$ 7.12-7.99 (m, $\left.11 \mathrm{H}, \mathrm{Ar}-\mathrm{H}\right)$, $4.23\left(\mathrm{dd}, 1 \mathrm{H}, \mathrm{H}_{\mathrm{A}}, \mathrm{J}_{\mathrm{AB}}=17.62 \mathrm{~Hz}, \mathrm{~J}_{\mathrm{AX}}=8.05 \mathrm{~Hz}\right), 4.26$ $\left(\mathrm{dd}, 1 \mathrm{H}, \mathrm{H}_{\mathrm{B}}, \mathrm{J}_{\mathrm{BA}}=17.62 \mathrm{~Hz}, \mathrm{~J}_{\mathrm{BX}}=4.27 \mathrm{~Hz}\right), 4.67(\mathrm{dd}, 1 \mathrm{H}$, $\left.\mathrm{H}_{\mathrm{X}}, \mathrm{J}_{\mathrm{XA}}=8.06 \mathrm{~Hz}, \mathrm{~J}_{\mathrm{XB}}=4.26 \mathrm{~Hz}\right), 9.21\left(\mathrm{~s}, 1 \mathrm{H}, \mathrm{NH}, \mathrm{D}_{2} \mathrm{O}\right.$ exchangeable), 1.29-3.56 (m, $11 \mathrm{H}, \mathrm{CH}_{2}$-cyclohexane); Anal. calcd. for $\mathrm{C}_{26} \mathrm{H}_{26} \mathrm{ClN}_{3} \mathrm{~S}$ : C, 69.70; H, 5.85; N, 9.38; Found: C, 69.73; H, 5.82; N, 9.40\%.

$\mathrm{N}$-cyclohexyl-3-(naphthalen-2-yl)-5-(2-nitrophenyl)4,5-dihydropyrazole-1-carbothioamide (4d)

Ochre (amorphous). m.p.: $120-125^{\circ} \mathrm{C}$; IR (KBr, cm $\left.{ }^{1}\right): 3359(\mathrm{NH}), 1586(\mathrm{C}=\mathrm{N}), 1364(\mathrm{C}=\mathrm{S}),{ }^{1} \mathrm{H}$ NMR $(300$ MHz, DMSO- $\left.d_{6}\right): \delta 7.02-8.05(\mathrm{~m}, 11 \mathrm{H}, \mathrm{Ar}-\mathrm{H}), 4.45(\mathrm{dd}$, $\left.1 \mathrm{H}, \mathrm{H}_{\mathrm{A}}, \mathrm{J}_{\mathrm{AB}}=17.74 \mathrm{~Hz}, \mathrm{~J}_{\mathrm{AX}}=7.96 \mathrm{~Hz}\right), 4.45\left(\mathrm{dd}, 1 \mathrm{H}, \mathrm{H}_{\mathrm{B}}\right.$, $\left.\mathrm{J}_{\mathrm{BA}}=17.74 \mathrm{~Hz}, \mathrm{~J}_{\mathrm{BX}}=4.32 \mathrm{~Hz}\right), 4.91\left(\mathrm{dd}, 1 \mathrm{H}, \mathrm{H}_{\mathrm{X}}, \mathrm{J}_{\mathrm{XA}}=8.06\right.$ $\left.\mathrm{Hz}, \mathrm{J}_{\mathrm{BX}}=4.33 \mathrm{~Hz}\right), 9.22\left(\mathrm{~s}, 1 \mathrm{H}, \mathrm{NH}, \mathrm{D}_{2} \mathrm{O}\right.$ exchangeable), 1.32-3.69 (m, $11 \mathrm{H}, \mathrm{CH}_{2}$-cyclohexane); Anal. calcd. for $\mathrm{C}_{26} \mathrm{H}_{26} \mathrm{~N}_{4} \mathrm{O}_{2} \mathrm{~S}: \mathrm{C}, 68.10 ; \mathrm{H}, 5.71 ; \mathrm{N}, 12.22$; Found: C, $68.12 ; \mathrm{H}, 5.75 ; \mathrm{N}, 12.20 \%$.

N-cyclohexyl-3-(naphthalen-2-yl)-5-(4-nitrophenyl)4,5-dihydropyrazole-1-carbothioamide (4e)

Mustard (amorphous). m.p.: $116-119^{\circ} \mathrm{C}$; IR ( $\mathrm{KBr}$, $\left.\mathrm{cm}^{-1}\right): 3366(\mathrm{NH}), 1588(\mathrm{C}=\mathrm{N}), 1347(\mathrm{C}=\mathrm{S}) ;{ }^{1} \mathrm{H}$ NMR $(300$ $\left.\mathrm{MHz}, \mathrm{CDCl}_{3}\right): \delta 7.12-8.04(\mathrm{~m}, 11 \mathrm{H}, \mathrm{Ar}-\mathrm{H}), 4.24(\mathrm{dd}, 1 \mathrm{H}$, $\left.\mathrm{H}_{\mathrm{A}}, \mathrm{J}_{\mathrm{AB}}=17.71 \mathrm{~Hz}, \mathrm{~J}_{\mathrm{AX}}=8.26 \mathrm{~Hz}\right), 4.28\left(\mathrm{dd}, 1 \mathrm{H}, \mathrm{H}_{\mathrm{B}}, \mathrm{J}_{\mathrm{BA}}\right.$ $\left.=17.71 \mathrm{~Hz}, \mathrm{~J}_{\mathrm{BX}}=4.37 \mathrm{~Hz}\right), 4.77\left(\mathrm{dd}, 1 \mathrm{H}, \mathrm{H}_{\mathrm{X}}, \mathrm{J}_{\mathrm{XA}}=8.24\right.$ $\left.\mathrm{Hz}, \mathrm{J}_{\mathrm{XB}}=4.35 \mathrm{~Hz}\right), 9.13\left(\mathrm{~s}, 1 \mathrm{H}, \mathrm{NH}, \mathrm{D}_{2} \mathrm{O}\right.$ exchangeable), 1.29-3.66 (m, $11 \mathrm{H}, \mathrm{CH}_{2}$-cyclohexane); Anal. calcd. for $\mathrm{C}_{26} \mathrm{H}_{26} \mathrm{~N}_{4} \mathrm{O}_{2} \mathrm{~S}: \mathrm{C}, 68.10 ; \mathrm{H}, 5.71 ; \mathrm{N}, 12.22$; Found: $\mathrm{C}$, $68.13 ; \mathrm{H}, 5.72 ; \mathrm{N}, 12.25 \%$.

5-(4-Bromophenyl)-3-(naphthalen-2-yl)-N-(p-tolyl)-4,5dihydropyrazole-1-carbothioamide (4f)

Brownish white (amorphous). m.p.: $140-145^{\circ} \mathrm{C}$; IR $\left(\mathrm{KBr}, \mathrm{cm}^{-1}\right): 3347(\mathrm{NH}), 1581(\mathrm{C}=\mathrm{N}), 1355(\mathrm{C}=\mathrm{S}),{ }^{1} \mathrm{H}$ NMR $\left(300 \mathrm{MHz}, \mathrm{CDCl}_{3}\right): \delta$ 7.07-7.94 (m, 15H, Ar-H), $4.16(\mathrm{dd}$, $\left.1 \mathrm{H}, \mathrm{H}_{\mathrm{A}}, \mathrm{J}_{\mathrm{AB}}=17.69 \mathrm{~Hz}, \mathrm{~J}_{\mathrm{AX}}=8.04 \mathrm{~Hz}\right), 4.31\left(\mathrm{dd}, 1 \mathrm{H}, \mathrm{H}_{\mathrm{B}}\right.$, $\left.\mathrm{J}_{\mathrm{BA}}=17.69 \mathrm{~Hz}, \mathrm{~J}_{\mathrm{BX}}=4.29 \mathrm{~Hz}\right), 4.68\left(\mathrm{dd}, 1 \mathrm{H}, \mathrm{H}_{\mathrm{X}}, \mathrm{J}_{\mathrm{XA}}=8.06\right.$ $\left.\mathrm{Hz}, \mathrm{J}_{\mathrm{XB}}=4.27 \mathrm{~Hz}\right), 9.16\left(\mathrm{~s}, 1 \mathrm{H}, \mathrm{NH}, \mathrm{D}_{2} \mathrm{O}\right.$ exchangeable), $2.21\left(\mathrm{~s}, 3 \mathrm{H}, \mathrm{CH}_{3}\right)$; Anal. calcd. for $\mathrm{C}_{27} \mathrm{H}_{22} \mathrm{BrN}_{3} \mathrm{~S}$ : C, 64.80; H, 4.43; N, 8.40; Found: C, 64.77; H, 4.47; N, 8.42\%.

3-(Naphthalen-2-yl)-5-phenyl-N-(p-tolyl)-4,5-

dihydropyrazole-1-carbothioamide (4g)

Yellowish-green (crystals). m.p.: $96-98^{\circ} \mathrm{C}$; IR ( $\mathrm{KBr}$, $\left.\mathrm{cm}^{-1}\right): 3400(\mathrm{NH}), 1561(\mathrm{C}=\mathrm{N}), 1365(\mathrm{C}=\mathrm{S}) ;{ }^{1} \mathrm{H} \mathrm{NMR}(300$
$\left.\mathrm{MHz}, \mathrm{CDCl}_{3}\right): \delta 7.10-7.94(\mathrm{~m}, 16 \mathrm{H}, \mathrm{Ar}-\mathrm{H}), 4.16(\mathrm{dd}, 1 \mathrm{H}$, $\left.\mathrm{H}_{\mathrm{A}}, \mathrm{J}_{\mathrm{AB}}=17.65 \mathrm{~Hz}, \mathrm{~J}_{\mathrm{AX}}=8.22 \mathrm{~Hz}\right), 4.32\left(\mathrm{dd}, 1 \mathrm{H}, \mathrm{H}_{\mathrm{B}}, \mathrm{J}_{\mathrm{BA}}=\right.$ $\left.17.65 \mathrm{~Hz}, \mathrm{~J}_{\mathrm{BX}}=4.27 \mathrm{~Hz}\right), 4.65\left(\mathrm{dd}, 1 \mathrm{H}, \mathrm{H}_{\mathrm{X}}, \mathrm{J}_{\mathrm{XA}}=8.21 \mathrm{~Hz}\right.$, $\left.\mathrm{J}_{\mathrm{XB}}=4.27 \mathrm{~Hz}\right), 9.13\left(\mathrm{~s}, 1 \mathrm{H}, \mathrm{NH}, \mathrm{D}_{2} \mathrm{O}\right.$ exchangeable), 2.18 (s, $3 \mathrm{H}, \mathrm{CH}_{3}$ ); Anal. calcd. for $\mathrm{C}_{27} \mathrm{H}_{23} \mathrm{~N}_{3} \mathrm{~S}: \mathrm{C}, 76.93 ; \mathrm{H}, 5.50$; N, 9.97; Found: C, 76.98; H, 5.47; N, 9.99\%.

\section{3-(Naphthalen-2-yl)-5-(2-nitrophenyl)-N-(p-tolyl)-4,5-}

dihydropyrazole-1-carbothioamide (4h)

Light yellow (amorphous). m.p: $138-140^{\circ} \mathrm{C}$; IR $\left(\mathrm{KBr}, \mathrm{cm}^{-1}\right): 3349(\mathrm{NH}), 1564(\mathrm{C}=\mathrm{N}), 1350(\mathrm{C}=\mathrm{S}) ;{ }^{1} \mathrm{H}$ NMR (300 MHz, $\left.\mathrm{CDCl}_{3}\right)$ : $\delta$ 7.04-8.05 (m, 15H, Ar-H), $4.37\left(\mathrm{dd}, 1 \mathrm{H}, \mathrm{H}_{\mathrm{A}}, \mathrm{J}_{\mathrm{AB}}=16.29 \mathrm{~Hz}, \mathrm{~J}_{\mathrm{AX}}=8.19 \mathrm{~Hz}\right), 4.43$ $\left(\mathrm{dd}, 1 \mathrm{H}, \mathrm{H}_{\mathrm{B}}, \mathrm{J}_{\mathrm{BA}}=16.29 \mathrm{~Hz}, \mathrm{~J}_{\mathrm{BX}}=4.29 \mathrm{~Hz}\right), 4.90(\mathrm{dd}$, $\left.1 \mathrm{H}, \mathrm{H}_{\mathrm{X}}, \mathrm{J}_{\mathrm{XA}}=8.20 \mathrm{~Hz}, \mathrm{~J}_{\mathrm{XB}}=4.27 \mathrm{~Hz}\right), 9.12(\mathrm{~s}, 1 \mathrm{H}, \mathrm{NH}$, $\mathrm{D}_{2} \mathrm{O}$ exchangeable), 2.17 (s, 3H, $\mathrm{CH}_{3}$ ); Anal. calcd. for $\mathrm{C}_{27} \mathrm{H}_{22} \mathrm{~N}_{4} \mathrm{O} 2 \mathrm{~S}: \mathrm{C}, 69.51 ; \mathrm{H}, 4.75 ; \mathrm{N}, 12.01$; Found: C, $69.57 ; \mathrm{H}, 4.72 ; \mathrm{N}, 12.03 \%$.

\section{3-(Naphthalen-2-yl)-5-(2-nitrophenyl)-N-phenyl-4,5- dihydropyrazole-1-carbothioamide (4i)}

Pale to dark yellow (amorphous). m.p.:150-154 ${ }^{\circ} \mathrm{C}$; IR $\left(\mathrm{KBr}, \mathrm{cm}^{-1}\right): 3339(\mathrm{NH}), 1579(\mathrm{C}=\mathrm{N}), 1361(\mathrm{C}=\mathrm{S}) ;{ }^{1} \mathrm{H}$ NMR (300 MHz, DMSO- $\left.d_{6}\right): \delta 6.94-8.07(\mathrm{~m}, 15 \mathrm{H}, \mathrm{Ar}-$ $\mathrm{H}), 4.36\left(\mathrm{dd}, 1 \mathrm{H}, \mathrm{H}_{\mathrm{A}}, \mathrm{J}_{\mathrm{AB}}=16.28 \mathrm{~Hz}, \mathrm{~J}_{\mathrm{AX}}=8.20 \mathrm{~Hz}\right), 4.43$ $\left(\mathrm{dd}, 1 \mathrm{H}, \mathrm{H}_{\mathrm{B}}, \mathrm{J}_{\mathrm{BA}}=16.28 \mathrm{~Hz}, \mathrm{~J}_{\mathrm{BX}}=4.28 \mathrm{~Hz}\right), 4.90(\mathrm{dd}, 1 \mathrm{H}$, $\left.\mathrm{H}_{\mathrm{X}}, \mathrm{J}_{\mathrm{XA}}=8.18 \mathrm{~Hz}, \mathrm{~J}_{\mathrm{XB}}=4.27 \mathrm{~Hz}\right), 9.12\left(\mathrm{~s}, 1 \mathrm{H}, \mathrm{NH}, \mathrm{D}_{2} \mathrm{O}\right.$ exchangeable); Anal. calcd. for $\mathrm{C}_{26} \mathrm{H}_{20} \mathrm{~N}_{4} \mathrm{O}_{2} \mathrm{~S}$ : C, 69.01; H, 4.45; N, 12.38; Found: C, 69.03; H, 4.41; N, 12.35\%.

5-(4-Chlorophenyl)-N-methyl-3-(naphthalen-2-yl)-4,5dihydro-1H-pyrazole-1-carbothioamide (4j)

Skin colored (crystals). m.p.: $124-126^{\circ} \mathrm{C}$; IR $\left(\mathrm{KBr}, \mathrm{cm}^{-1}\right): 3303(\mathrm{NH}), 1566(\mathrm{C}=\mathrm{N}), 1349(\mathrm{C}=\mathrm{S}) ;{ }^{1} \mathrm{H}$ NMR $\left(300 \mathrm{MHz}, \mathrm{CDCl}_{3}\right): \delta 7.22-7.94(\mathrm{~m}, 11 \mathrm{H}, \mathrm{Ar}-\mathrm{H})$, $4.19\left(\mathrm{dd}, 1 \mathrm{H}, \mathrm{H}_{\mathrm{A}}, \mathrm{J}_{\mathrm{AB}}=17.69 \mathrm{~Hz}, \mathrm{~J}_{\mathrm{AX}}=8.19 \mathrm{~Hz}\right), 4.25$ $\left(\mathrm{dd}, 1 \mathrm{H}, \mathrm{H}_{\mathrm{B}}, \mathrm{J}_{\mathrm{BA}}=17.69 \mathrm{~Hz}, \mathrm{~J}_{\mathrm{BX}}=4.31 \mathrm{~Hz}\right), 4.66(\mathrm{dd}$, $\left.1 \mathrm{H}, \mathrm{H}_{\mathrm{X}}, \mathrm{J}_{\mathrm{XA}}=8.20 \mathrm{~Hz}, \mathrm{~J}_{\mathrm{XB}}=4.29 \mathrm{~Hz}\right), 9.19(\mathrm{~s}, 1 \mathrm{H}, \mathrm{NH}$, $\mathrm{D}_{2} \mathrm{O}$ exchangeable), $2.44\left(\mathrm{~s}, 3 \mathrm{H}, \mathrm{CH}_{3}\right)$; Anal. calcd. for $\mathrm{C}_{21} \mathrm{H}_{18} \mathrm{ClN}_{3} \mathrm{~S}$ : C, 66.39; H, 4.78; N, 11.06; Found: C, 66.44; H, 4.76; N, 11.09\%.

N-methyl-3-(naphthalen-2-yl)-5-(4-nitrophenyl)-4,5dihydropyrazole-1-carbothioamide (4k)

Dark yellow (amorphous). m.p.: 110-115 ${ }^{\circ} \mathrm{C}$; IR $\left(\mathrm{KBr}, \mathrm{cm}^{-1}\right): 3386(\mathrm{NH}), 1580(\mathrm{C}=\mathrm{N}), 1353(\mathrm{C}=\mathrm{S}) ;{ }^{1} \mathrm{H}$ NMR $\left(300 \mathrm{MHz}, \mathrm{CDCl}_{3}\right): \delta 7.19-8.03(\mathrm{~m}, 11 \mathrm{H}, \mathrm{Ar}-\mathrm{H})$, $4.28\left(\mathrm{dd}, 1 \mathrm{H}, \mathrm{H}_{\mathrm{A}}, \mathrm{J}_{\mathrm{AB}}=17.59 \mathrm{~Hz}, \mathrm{~J}_{\mathrm{AX}}=8.06 \mathrm{~Hz}\right), 4.28$ $\left(\mathrm{dd}, 1 \mathrm{H}, \mathrm{H}_{\mathrm{B}}, \mathrm{J}_{\mathrm{BA}}=17.59 \mathrm{~Hz}, \mathrm{~J}_{\mathrm{BX}}=4.27 \mathrm{~Hz}\right), 4.76(\mathrm{dd}$, $\left.1 \mathrm{H}, \mathrm{H}_{\mathrm{X}}, \mathrm{J}_{\mathrm{XA}}=8.07 \mathrm{~Hz}, \mathrm{~J}_{\mathrm{XB}}=4.29 \mathrm{~Hz}\right), 9.21(\mathrm{~s}, 1 \mathrm{H}, \mathrm{NH}$, $\mathrm{D}_{2} \mathrm{O}$ exchangeable), 2.39 (s, $3 \mathrm{H}, \mathrm{CH}_{3}$ ); Anal. calcd. for 
$\mathrm{C}_{21} \mathrm{H}_{18} \mathrm{~N}_{4} \mathrm{O}_{2} \mathrm{~S}: \mathrm{C}, 64.60 ; \mathrm{H}, 4.65 ; \mathrm{N}, 14.35$; Found: $\mathrm{C}$, $64.58 ; \mathrm{H}, 4.66 ; \mathrm{N}, 14.38 \%$.

5-(4-Bromophenyl)-N-methyl-3-(naphthalen-2-yl)-4,5dihydropyrazole-1-carbothioamide (4I)

Light brown (amorphous). m.p.: $160-164^{\circ} \mathrm{C}$; IR (KBr, $\left.\mathrm{cm}^{-1}\right): 3412(\mathrm{NH}), 1575(\mathrm{C}=\mathrm{N}), 1370(\mathrm{C}=\mathrm{S}) ;{ }^{1} \mathrm{H} \mathrm{NMR}(300$ $\left.\mathrm{MHz}, \mathrm{CDCl}_{3}\right): \delta 6.89-7.94(\mathrm{~m}, 11 \mathrm{H}, \mathrm{Ar}-\mathrm{H}), 4.23(\mathrm{dd}, 1 \mathrm{H}$, $\left.\mathrm{H}_{\mathrm{A}}, \mathrm{J}_{\mathrm{AB}}=17.67 \mathrm{~Hz}, \mathrm{~J}_{\mathrm{AX}}=8.16 \mathrm{~Hz}\right), 4.27\left(\mathrm{dd}, 1 \mathrm{H}, \mathrm{H}_{\mathrm{B}}, \mathrm{J}_{\mathrm{BA}}=\right.$ $\left.17.67 \mathrm{~Hz}, \mathrm{~J}_{\mathrm{BX}}=4.27 \mathrm{~Hz}\right), 4.66\left(\mathrm{dd}, 1 \mathrm{H}, \mathrm{H}_{\mathrm{X}}, \mathrm{J}_{\mathrm{XA}}=8.17 \mathrm{~Hz}\right.$, $\left.\mathrm{J}_{\mathrm{XB}}=4.28 \mathrm{~Hz}\right), 9.23\left(\mathrm{~s}, 1 \mathrm{H}, \mathrm{NH}, \mathrm{D}_{2} \mathrm{O}\right.$ exchangeable), $2.42(\mathrm{~s}$, $3 \mathrm{H}, \mathrm{CH}_{3}$ ); Anal. calcd. for $\mathrm{C}_{21} \mathrm{H}_{18} \mathrm{BrN}_{3} \mathrm{~S}: \mathrm{C}, 59.44 ; \mathrm{H}, 4.28$; N, 9.90; Found: C, 59.51; H, 4.26; N, 9.95\%.

$\mathrm{N}$-methyl-3-(naphthalen-2-yl)-5-(2-nitrophenyl)-4,5dihydropyrazole-1-carbothioamide (4m)

Pale yellow (amorphous). m.p.: $146-148^{\circ} \mathrm{C}$; IR $\left(\mathrm{KBr}, \mathrm{cm}^{-1}\right): 3378(\mathrm{NH}), 1571(\mathrm{C}=\mathrm{N}), 1348(\mathrm{C}=\mathrm{S}) ;{ }^{1} \mathrm{H}$ $\operatorname{NMR}\left(300 \mathrm{MHz}, \mathrm{CDCl}_{3}\right): \delta 7.12-8.05(\mathrm{~m}, 11 \mathrm{H}, \mathrm{Ar}-\mathrm{H})$, $4.44(\mathrm{~d}, 1 \mathrm{H}, \mathrm{J}=8.19 \mathrm{~Hz}), 4.44(\mathrm{~d}, 1 \mathrm{H}, 4.28 \mathrm{~Hz}), 4.90$ $\left(\mathrm{dd}, 1 \mathrm{H}, \mathrm{H}_{\mathrm{X}}, \mathrm{J}_{\mathrm{XA}}=8.18 \mathrm{~Hz}, \mathrm{~J}_{\mathrm{XB}}=4.17 \mathrm{~Hz}\right), 9.25(\mathrm{~s}, 1 \mathrm{H}$, $\mathrm{NH}, \mathrm{D}_{2} \mathrm{O}$ exchangeable), $2.397\left(\mathrm{~s}, 3 \mathrm{H}, \mathrm{CH}_{3}\right.$ ); Anal. calcd. for $\mathrm{C}_{21} \mathrm{H}_{18} \mathrm{~N}_{4} \mathrm{O}_{2} \mathrm{~S}$ : C, 64.60; H, 4.65; N, 14.35; Found: C, $64.58 ; \mathrm{H}, 4.67 ; \mathrm{N}, 14.39 \%$.

5-(4-Bromophenyl)-N-ethyl-3-(naphthalen-2-yl)-4,5dihydropyrazole-1-carbothioamide (4n)

Dark brown (amorphous). m.p.: 89-92 ${ }^{\circ} \mathrm{C}$; IR $\left(\mathrm{KBr}, \mathrm{cm}^{-1}\right): 3232(\mathrm{NH}), 1577(\mathrm{C}=\mathrm{N}), 1373(\mathrm{C}=\mathrm{S}) ;{ }^{1} \mathrm{H}$ NMR $\left(300 \mathrm{MHz}, \mathrm{CDCl}_{3}\right): \delta 6.85-7.99(\mathrm{~m}, 11 \mathrm{H}, \mathrm{Ar}-\mathrm{H})$, $4.24\left(\mathrm{dd}, 1 \mathrm{H}, \mathrm{H}_{\mathrm{A}}, \mathrm{J}_{\mathrm{AB}}=17.65 \mathrm{~Hz}, \mathrm{~J}_{\mathrm{AX}}=8.06 \mathrm{~Hz}\right), 4.27$ $\left(\mathrm{dd}, 1 \mathrm{H}, \mathrm{H}_{\mathrm{B}}, \mathrm{J}_{\mathrm{BA}}=17.65 \mathrm{~Hz}, \mathrm{~J}_{\mathrm{BX}}=4.27 \mathrm{~Hz}\right), 4.66(\mathrm{dd}, 1 \mathrm{H}$, $\left.\mathrm{H}_{\mathrm{X}}, \mathrm{J}_{\mathrm{XA}}=8.07 \mathrm{~Hz}, \mathrm{~J}_{\mathrm{XB}}=4.28 \mathrm{~Hz}\right), 9.21\left(\mathrm{~s}, 1 \mathrm{H}, \mathrm{NH}, \mathrm{D}_{2} \mathrm{O}\right.$ exchangeable), 1.22 (triplet, $3 \mathrm{H}, \mathrm{CH}_{2} \mathrm{CH}_{3}$ ), 3.19 (quartet, $2 \mathrm{H}, \mathrm{CH}_{2} \mathrm{CH}_{3}$ ); Anal. calcd. for $\mathrm{C}_{22} \mathrm{H}_{20} \mathrm{BrN}_{3} \mathrm{~S}$ : C, 60.27; H, 4.60; N, 9.59; Found: C, 60.33; H, 4.62; N, 9.56\%.

\section{Molecular docking}

The molecular docking study was carried out in order to assess their interaction and binding modes with target receptor and good biological activity using Glide extra precision (XP) Maestro 10.1 Schrodinger, running on Linux 64 operating system (Schrodinger, 2016). The 2D structure of synthesized compounds was generated and then converted to their respective 3D structures with the use of Ligprep. The X-ray crystal structure of 2A1H (PDB ID) was downloaded from Protein Data Bank solved at a resolution of $1.8 \AA$. The protein was prepared using the protein preparation wizard and the grid was generated for co-crystal ligand. The water residues beyond $5 \AA$ were eliminated. The protein was optimized by assigning $\mathrm{H}$-bonds and minimization at OPLS 2005 force field. Molecular docking studies mainly involve selection and preparation of appropriate protein, grid generation, ligand preparation followed by docking \& its analysis. The docking score, hydrogen bonds and pi-pi interactions formed with the enclosed amino acids were used to conclude their binding affinities and proper alignment of these compounds at the active site of the receptor. Binding energy estimation can be used to calculate ligand binding energies and strain of ligand energies for a set of ligand on a single receptor using the Prime molecular mechanics-generalized born surface area (MM-GBSA) method, Maestro 10.1. The ligands and the receptors were prepared by using LigPrep and Protein preparation wizard. The binding poses for compound were analyzed by examining their free energy scores.

\section{Pharmacology}

The pharmacological testing of all the final compounds was performed according to the standard protocol given by epilepsy branch of the National Institute of Neurological Disorders and Stroke (NINDS), NIH, Rockville, MD 20892, USA following the protocol adopted by the Antiepileptic Drug Development (ADD) program. The investigations were conducted on albino mice (20-24 g) of either sex. The albino mice were kept under standard conditions at an ambient temperature of $25 \pm 2{ }^{\circ} \mathrm{C}$. Food and water were withdrawn prior to the experiment. The synthesized compounds were tested against the standard drugs phenytoin and carbamazepine at a dose of 30,100 and $300 \mathrm{mg} / \mathrm{kg}$ i.p. The solution of standard drugs and test compounds were prepared in propylene glycol.

\section{Maximal electroshock seizure Test (MES Test)}

In this test (Krall et al., 1978), mice were prescreened 24 hours before by delivering maximal electroshock ( $50 \mathrm{~mA} ; 60 \mathrm{~Hz}$ and $0.2 \mathrm{~s}$ duration) by means of corneal electrodes. A drop of $0.9 \%$ sodium chloride was instilled in each eye prior to the application of electrodes in order to prevent the death of the animal. Test solutions of all compounds were dosed intraperitoneally $30 \mathrm{~min}$ prior to testing. Abolition of hind limb tonic extensor component of the seizure in half or more of the animals is defined as protection.

\section{Sub-cutaneous Pentylenetetrazole Test (scPTZ Test)}

The scPTZ test (Swinyard et al., 1989) utilized a dose of pentylenetetrazole $85 \mathrm{mg} / \mathrm{kg}$ s.c. This produced 
clonic seizure lasting for a period of at least 5 seconds. The test compounds were administered at the three graded doses of 30,100 and $300 \mathrm{mg} / \mathrm{kg}$ i.p. At the anticipated time, the convulsant was administered subcutaneously. Animals were observed over a $30 \mathrm{~min}$ period. The absence of clonic spasm in half or more of the animals in the observed time period indicated a compounds ability to abolish the effect of pentylenetetrazole on seizure threshold.

\section{Neurotoxicity study}

Rotarod Test: The minimal motor impairment was measured in mice by rotarod test (Dunham, Miya, Edwards, 1957). The mice were trained to stay on an accelerating rotarod of diameter $3.2 \mathrm{~cm}$ that rotates at 10 $\mathrm{rpm}$. Neurotoxicity was indicated by the inability of the animal to maintain equilibrium on the rod for at least one minute in each of the three trials. The dose at which $50 \%$ of the animals enabled to balance themselves and full off the rotating rod was determined.

\section{RESULTS AND DISCUSSION}

\section{Chemistry}

The present work is focused on the synthesis, characterization, molecular docking study and anticonvulsant evaluation of $N$-substituted-3-(napthalen2-yl)-5-substituted phenyl-4,5-dihydropyrazole-1carbothioamide derivatives. A series of 15 compounds were synthesized as per the synthetic route described in Scheme 1. The physicochemical parameters of the synthesized pyrazoline derivatives are given in Table I.

The synthesized compounds were characterized by elemental and spectral analysis (FT-IR and ${ }^{1} \mathrm{H}$ NMR). Characterization was done after crystallization from appropriate solvents. The synthesized compounds were found to have $\mathrm{N}-\mathrm{H}, \mathrm{C}=\mathrm{N}$ and $\mathrm{C}=\mathrm{S}$ stretching bands in the region of 3466-3232, 1588-1570 and 1373-1347 $\mathrm{cm}^{-1}$, respectively, in the IR spectra. The ${ }^{1} \mathrm{H}$ NMR spectra of compounds were recorded in $\mathrm{CDCl}_{3}$ ' DMSO- $d_{6}$ solvent using TMS as an internal standard. In ${ }^{1} \mathrm{H}$ NMR, these compounds exhibited multiplets for Ar-H in the regions of 6.859-8.076 ppm, a singlet in the region of 9.198-9.242 ppm for $(\mathrm{N}-\mathrm{H})$. The $\mathrm{CH}_{2}$ protons of the pyrazoline ring were found to resonate as a pair of doublets at 4.162-4.456 ppm $\left(\mathrm{H}_{\mathrm{A}}\right), 4.242-4.454 \mathrm{ppm}$ $\left(\mathrm{H}_{\mathrm{B}}\right)$. Furthermore, the $\mathrm{CH}\left(\mathrm{H}_{\mathrm{X}}\right)$ proton appeared as doublets at 4.631-4.916 ppm due to vicinal coupling with the two magnetically non-equivalent protons of the methylene group at position 4 of the pyrazoline
$\operatorname{ring}\left(J_{A B}: 17.65-18.40 \mathrm{~Hz}, J_{A X}: 2.90-8.01 \mathrm{~Hz}, J_{B X}\right.$ : $11.07-13.28 \mathrm{~Hz})$.

\section{Pharmacological evaluation}

The pharmacological evaluation for anticonvulsant and neurotoxicity was performed as per the standard methods proposed by NIH anticonvulsant drug development (ADD) program (Stables et al., 1978), via the anticonvulsant screening project (ASP). The evaluation included the maximal electroshock (MES), subcutaneous pentylenetetrazole (scPTZ) and neurotoxicity (Tox). In the testing, the compounds (4a-n) were administered i.p. into mice at dose of 30,100 and $300 \mathrm{mg} / \mathrm{kg}$ and observations were taken at two different intervals $(0.5 \mathrm{~h}$ and $4 \mathrm{~h}$ ). Neurotoxicity was measured by rotarod test. The results are shown in Table II. The results revealed that the compounds $\mathbf{4 a}, \mathbf{4 d}, \mathbf{4 e}, \mathbf{4 g}, \mathbf{4 i}, \mathbf{4 j}, \mathbf{4 l}$ and $\mathbf{4 n}$ possessed good anticonvulsant activity against the MES model at $30 \mathrm{mg} / \mathrm{kg}$ at time period of $0.5 \mathrm{~h}$ indicating their good ability to prevent seizure spread.Whereas compound $\mathbf{4 a}$, 4e, 4f, 4g, 4i $4 \mathbf{j}$ and $\mathbf{4 n}$ showed anticonvulsant activity against standards carbamazepine and phenytoin at a dose of $100 \mathrm{mg} / \mathrm{kg}$ at the time period of $0.5 \mathrm{~h}$, indicating their ability to prevent seizure spread at relatively higher dose. At a dose level of $300 \mathbf{m g} / \mathrm{kg}, \mathbf{4} \mathbf{g}$ and $\mathbf{4 j}$ showed good anticonvulsant activity at time period of $0.5 \mathrm{~h}$ concluding that these compounds have rapid onset of action at higher dose level. Compounds $\mathbf{4 i}$ and $\mathbf{4} \mathbf{j}$ showed good anticonvulsant behavior at a dose level of $30 \mathrm{mg} / \mathrm{kg}$ even at time period of $4 \mathrm{~h}$, indicating their long duration of action at a lower dose. Among all, compounds $\mathbf{4 g}, \mathbf{4 i}, \mathbf{4 j}$ and $\mathbf{4 n}$ showed full protection at a dose of $100 \mathrm{mg} / \mathrm{kg}$ at the time period of $0.5 \mathrm{~h}$ and can be further explored to know the mechanism of action.

In the scPTZ test, compound $\mathbf{4 e}$ and $\mathbf{4 l}$ showed good inhibition of clonic and tonic seizures at $30 \mathrm{mg} / \mathrm{kg}$ at $0.5 \mathrm{~h}$. However, some level of inhibition was observed with $\mathbf{4 e}$, $4 \mathbf{j}$ and $4 \mathrm{n}$ at a higher dose of $100 \mathrm{mg} / \mathrm{kg}$ at $0.5 \mathrm{~h}$ duration. Compound $4 \mathbf{i}$ was inactive at $0.5 \mathrm{~h}$ but showed inhibition of seizure at $30 \mathrm{mg} / \mathrm{kg}$ at a time period of $4 \mathrm{~h}$, showing that this compound has long duration of action at a lower dose. Rest of the compounds in MES and scPTZ test were either inactive or didn't show any significant results. In neurotoxicity screening, the results indicated absence of neurotoxicity in most of the tested compounds at 30, 100 and $300 \mathrm{mg} / \mathrm{kg}$. Only compound $\mathbf{4 b}, \mathbf{4 c}, \mathbf{4 h}$ and $\mathbf{4 k}$ were found neurotoxic at a higher dose of $300 \mathrm{mg} / \mathrm{kg}$.

On structure correlation of compounds with anticonvulsant activity showed that compounds substituted with electron-withdrawing group $\left(\mathrm{NO}_{2}\right.$, chloro or bromo $)$ 
<smiles>[R]c1cccc(C=O)c1</smiles><smiles>O=C(CCc1ccccc1)c1ccc2ccccc2c1</smiles>

(1a-c)

$$
\text { Alkyl/Aryl- } \mathrm{NH}_{2}+\mathrm{CS}_{2}
$$

(b)<smiles>[R]Cc1ccccc1C1CC(c2ccc3ccccc3c2)=NN1</smiles>

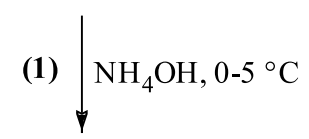

SCHEME 1 - Reagents and conditions: (a) EtOH, 0-5 ${ }^{\circ} \mathrm{C}$; (b) $\mathrm{NH}_{2} \mathrm{NH}_{2} \cdot 2 \mathrm{H}_{2} \mathrm{O}$, Room temp; (c) alkyl/aryl/NCS

at second and fourth position of hydrophobic aryl ring with hexyl, phenyl, methyl or ethyl substitution at distal aryl ring were found responsible for excellent anticonvulsant activity.

\section{Lipophilicity}

The Clog P values are the indicative of the importance of lipophilicity as electronic properties of substituents 
TABLE I - Physicochemical parameters of the synthesized compounds (4a-n)

\begin{tabular}{|c|c|c|c|c|c|c|c|c|}
\hline Compd. no. & $\mathbf{R}$ & $\mathbf{R}_{1}$ & $\begin{array}{l}\text { Molecular } \\
\text { Formula }^{\mathrm{a}}\end{array}$ & Mol. Wt. & Yield (\%) & $\mathbf{R}_{\mathrm{f}}^{\mathrm{b}}$ & $C \log P^{c}$ & $\mathbf{R}_{\mathrm{m}}$ \\
\hline $4 a$ & $4-\mathrm{Br}$ & & $\mathrm{C}_{26} \mathrm{H}_{26} \mathrm{BrN}_{3} \mathrm{~S}$ & 492.47 & 85 & 0.65 & 7.28 & -0.22 \\
\hline $4 b$ & $\mathrm{H}$ & & $\mathrm{C}_{26} \mathrm{H}_{27} \mathrm{~N}_{3} \mathrm{~S}$ & 413.58 & 80 & 0.80 & 6.42 & -0.39 \\
\hline $4 c$ & $4-\mathrm{Cl}$ & & $\mathrm{C}_{26} \mathrm{H}_{26} \mathrm{ClN}_{3} \mathrm{~S}$ & 448.02 & 80 & 0.73 & 7.13 & -0.69 \\
\hline $4 d$ & $2-\mathrm{NO}_{2}$ & & $\mathrm{C}_{26} \mathrm{H}_{26} \mathrm{~N}_{4} \mathrm{O}_{2} \mathrm{~S}$ & 458.58 & 86 & 0.71 & 6.08 & -0.39 \\
\hline $4 e$ & $4-\mathrm{NO}_{2}$ & & $\mathrm{C}_{26} \mathrm{H}_{26} \mathrm{~N}_{4} \mathrm{O}_{2} \mathrm{~S}$ & 458.58 & 84 & 0.80 & 6.16 & -0.69 \\
\hline $4 f$ & $4-\mathrm{Br}$ & & $\mathrm{C}_{27} \mathrm{H}_{22} \mathrm{BrN}_{3} \mathrm{~S}$ & 500.45 & 82 & 0.82 & 7.18 & -0.39 \\
\hline $4 g$ & $\mathrm{H}$ & & $\mathrm{C}_{27} \mathrm{H}_{23} \mathrm{~N}_{3} \mathrm{~S}$ & 421.56 & 84 & 0.72 & 6.32 & -0.69 \\
\hline $4 h$ & $2-\mathrm{NO}_{2}$ & & $\mathrm{C}_{27} \mathrm{H}_{22} \mathrm{~N}_{4} \mathrm{O}_{2} \mathrm{~S}$ & 466.55 & 83 & 0.67 & 5.98 & -0.22 \\
\hline $4 i$ & $2-\mathrm{NO}_{2}$ & & $\mathrm{C}_{26} \mathrm{H}_{20} \mathrm{~N}_{4} \mathrm{O}_{2} \mathrm{~S}$ & 452.53 & 81 & 0.62 & 5.49 & -0.22 \\
\hline $4 j$ & $4-\mathrm{Cl}$ & $\mathrm{CH}_{3}$ & $\mathrm{C}_{21} \mathrm{H}_{18} \mathrm{ClN}_{3} \mathrm{~S}$ & 379.91 & 79 & 0.85 & 5.10 & -0.69 \\
\hline $4 k$ & $4-\mathrm{NO}_{2}$ & $\mathrm{CH}_{3}$ & $\mathrm{C}_{21} \mathrm{H}_{18} \mathrm{~N}_{4} \mathrm{O}_{2} \mathrm{~S}$ & 390.46 & 84 & 0.74 & 4.13 & -0.39 \\
\hline 41 & $4-\mathrm{Br}$ & $\mathrm{CH}_{3}$ & $\mathrm{C}_{21} \mathrm{H}_{18} \mathrm{BrN}_{3} \mathrm{~S}$ & 424.36 & 80 & 0.81 & 5.25 & -0.69 \\
\hline $4 m$ & $2-\mathrm{NO}_{2}$ & $\mathrm{CH}_{3}$ & $\mathrm{C}_{21} \mathrm{H}_{18} \mathrm{~N}_{4} \mathrm{O}_{2} \mathrm{~S}$ & 390.46 & 76 & 0.70 & 4.05 & -0.39 \\
\hline $4 n$ & $4-\mathrm{Br}$ & $\mathrm{CH}_{2} \mathrm{CH}_{3}$ & $\mathrm{C}_{22} \mathrm{H}_{20} \mathrm{BrN}_{3} \mathrm{~S}$ & 438.38 & 80 & 0.80 & 5.78 & -0.69 \\
\hline
\end{tabular}

${ }^{a}$ Elemental analysis for $\mathrm{C}, \mathrm{H}, \mathrm{N}$ were within $\pm 0.4 \%$ of the theoretical values. ${ }^{\mathrm{b}}$ Solvent system used toluene:acetone $(8: 2)$. ${ }^{c} C \log$ P: calculated using software Chem. Draw ultra 12.0. $R_{m}$ values were calculated by the formula $R_{m}=\log \left[\left(1 / R_{f}-1\right)\right]$

on the activity of these compounds. The relatively favorable anticonvulsant activity for all the compounds displayed Clog P values 4.39-7.28. The lipophilicity of the compounds shown by $\mathrm{R}_{\mathrm{m}}$ value was found to be in the range of -0.22 to -1.00 , which can be considered to be optimum lipophilicity for the congeners that act on the central nervous system are summarized in Table I.

\section{Molecular docking}

The molecular docking studies were performed to establish the binding ability of the synthesized compounds to the human cytosolic branched chain amino transferase (hBCATc) (Gotoet al., 2005). The docking scores and binding free energy of all the compounds and co-crystal ligand (gabapentin) with the active site of human cytosolic branched chain amino transferase (hBCATc) were summarized in Table III. The results of docking studies showed that thirteen compounds (4an) exhibited higher docking score than that of co-crystal (gabapentin)suggesting that the synthesized compounds (4a-n) displayed better interaction with hBCATc.The 
TABLE II - Anticonvulsant activity and neurotoxicity screening of compounds (4a-n).

\begin{tabular}{|c|c|c|c|c|c|c|c|c|c|c|c|c|c|c|c|c|c|c|}
\hline \multirow{3}{*}{$\begin{array}{l}\text { Test } \\
\text { Time } \\
\text { Dose } \\
(\mathrm{mg} / \mathrm{kg})\end{array}$} & \multicolumn{6}{|c|}{ MES } & \multicolumn{6}{|c|}{ scPTZ } & \multicolumn{6}{|c|}{ Tox } \\
\hline & \multicolumn{3}{|c|}{$0.5 \mathrm{~h}$} & \multicolumn{3}{|c|}{$4 \mathrm{~h}$} & \multicolumn{3}{|c|}{$0.5 \mathrm{~h}$} & \multicolumn{3}{|c|}{$4 \mathrm{~h}$} & \multicolumn{3}{|c|}{$0.5 \mathrm{~h}$} & \multicolumn{3}{|c|}{$4 \mathrm{~h}$} \\
\hline & 30 & 100 & 300 & 30 & 100 & 300 & 30 & 100 & 300 & 30 & 100 & 300 & 30 & 100 & 300 & 30 & 100 & 300 \\
\hline $4 a$ & $2 / 4$ & $2 / 4$ & $0 / 4$ & $1 / 4$ & $1 / 4$ & $0 / 4$ & $1 / 4$ & $\mathrm{x}$ & $\mathrm{x}$ & $\mathrm{x}$ & $\mathrm{x}$ & $\mathrm{x}$ & - & - & - & - & - & - \\
\hline $4 b$ & $1 / 4$ & $0 / 4$ & $0 / 4$ & $0 / 4$ & $0 / 4$ & $0 / 4$ & $\mathrm{x}$ & $\mathrm{x}$ & $\mathrm{x}$ & $\mathrm{x}$ & $\mathrm{x}$ & $\mathrm{x}$ & - & - & - & - & - & $4 / 4$ \\
\hline $4 c$ & $1 / 4$ & $1 / 4$ & $1 / 4$ & $0 / 4$ & $1 / 4$ & $1 / 4$ & $\mathrm{x}$ & $\mathrm{x}$ & $\mathrm{x}$ & $\mathrm{x}$ & $\mathrm{x}$ & $\mathrm{x}$ & - & - & $2 / 4$ & - & - & - \\
\hline $4 d$ & $2 / 4$ & $1 / 4$ & $1 / 4$ & $1 / 4$ & $0 / 4$ & $0 / 4$ & $1 / 4$ & $\mathrm{x}$ & $\mathrm{x}$ & $\mathrm{x}$ & $\mathrm{x}$ & $\mathrm{x}$ & - & - & - & - & - & - \\
\hline $4 e$ & $2 / 4$ & $3 / 4$ & $1 / 4$ & $0 / 4$ & $1 / 4$ & $0 / 4$ & $3 / 4$ & $2 / 4$ & $\mathrm{x}$ & $\mathrm{x}$ & $\mathrm{x}$ & $\mathrm{x}$ & _- & _ & _ & _ & _ & _ \\
\hline $4 f$ & $1 / 4$ & $2 / 4$ & $1 / 4$ & $1 / 4$ & $0 / 4$ & $0 / 4$ & $\mathrm{x}$ & $1 / 4$ & $\mathrm{x}$ & $\mathrm{x}$ & $\mathrm{x}$ & $\mathrm{x}$ & _ & _ & _ & _ & _ & _ \\
\hline $4 g$ & $2 / 4$ & $4 / 4$ & $2 / 4$ & $1 / 4$ & $1 / 4$ & $0 / 4$ & $1 / 4$ & $1 / 4$ & $\mathrm{x}$ & $\mathrm{x}$ & $\mathrm{x}$ & $\mathrm{x}$ & - & - & - & - & - & - \\
\hline $4 h$ & $0 / 4$ & $1 / 4$ & $0 / 4$ & $1 / 4$ & $1 / 4$ & $0 / 4$ & $\mathrm{x}$ & $\mathrm{x}$ & $\mathrm{x}$ & $\mathrm{x}$ & $\mathrm{x}$ & $\mathrm{x}$ & - & - & - & - & - & $1 / 4$ \\
\hline $4 i$ & $3 / 4$ & $4 / 4$ & $1 / 4$ & $2 / 4$ & $0 / 4$ & $0 / 4$ & $0 / 4$ & $\mathrm{x}$ & $\mathrm{x}$ & $2 / 4$ & $\mathrm{x}$ & $\mathrm{x}$ & - & - & - & - & - & - \\
\hline $4 \mathbf{j}$ & $3 / 4$ & $4 / 4$ & $2 / 4$ & $2 / 4$ & $1 / 4$ & $0 / 4$ & $1 / 4$ & $2 / 4$ & $\mathrm{x}$ & $1 / 4$ & $\mathrm{x}$ & $\mathrm{x}$ & - & - & - & - & - & - \\
\hline $4 k$ & $1 / 4$ & $0 / 4$ & $1 / 4$ & $0 / 4$ & $0 / 4$ & $0 / 4$ & $\mathrm{x}$ & $\mathrm{x}$ & $\mathrm{x}$ & $\mathrm{x}$ & $\mathrm{x}$ & $\mathrm{x}$ & - & - & $1 / 4$ & - & - & $1 / 4$ \\
\hline 41 & $2 / 4$ & $1 / 4$ & $1 / 4$ & $1 / 4$ & $1 / 4$ & $0 / 4$ & $3 / 4$ & $\mathrm{x}$ & $\mathrm{x}$ & $\mathrm{x}$ & $\mathrm{x}$ & $\mathrm{x}$ & _- & - & - & - & - & - \\
\hline $4 m$ & $1 / 4$ & $1 / 4$ & $1 / 4$ & $0 / 4$ & $0 / 4$ & $0 / 4$ & $\mathrm{x}$ & $\mathrm{x}$ & $\mathrm{x}$ & $\mathrm{x}$ & $\mathrm{x}$ & $\mathrm{x}$ & - & - & - & - & - & - \\
\hline 4n & $2 / 4$ & $4 / 4$ & $1 / 4$ & $1 / 4$ & $1 / 4$ & $0 / 4$ & $\mathrm{x}$ & $2 / 4$ & $\mathrm{x}$ & $\mathrm{x}$ & $\mathrm{x}$ & $\mathrm{x}$ & _ & _- & _ & _- & _- & _ \\
\hline Phenytoin & $4 / 4$ & $4 / 4$ & $4 / 4$ & $4 / 4$ & $4 / 4$ & $4 / 4$ & $0 / 0$ & $0 / 4$ & $0 / 4$ & $0 / 4$ & $0 / 4$ & $0 / 4$ & $0 / 4$ & $0 / 4$ & $0 / 4$ & $0 / 4$ & $4 / 4$ & $4 / 4$ \\
\hline Carbamazepine & $4 / 4$ & $4 / 4$ & $4 / 4$ & $0 / 4$ & $4 / 4$ & $4 / 4$ & $0 / 4$ & $0 / 4$ & $4 / 4$ & $0 / 4$ & $4 / 4$ & $4 / 4$ & $0 / 4$ & $0 / 4$ & $4 / 4$ & $0 / 4$ & $0 / 4$ & $0 / 4$ \\
\hline
\end{tabular}

MES: Maximal electroshock seizure test (number of animal protected/number of animal tested). scPTZ: subcutaneous pentylenetetrazole test (number of animal protected/number of animal tested). Tox: rotarod test (number of animal exhibiting toxicity/number of animal tested). Solvent used: propylene glycol (0.1 mL, i.p.). (-): indicates absence of neurotoxicity. (x): indicates compounds not tested.

TABLE III - Docking scores and binding free energy of compounds (4a-n)

\begin{tabular}{ccc}
\hline Compounds & Docking Scores & $\begin{array}{c}\text { Binding Free } \\
\text { Energy (Kcal/mol) }\end{array}$ \\
\hline $\mathbf{4 e}$ & -4.28 & -61.44 \\
$\mathbf{4 b}$ & -4.27 & -63.13 \\
$\mathbf{4 j}$ & -4.01 & -55.17 \\
$\mathbf{4} \mathbf{f}$ & -3.74 & -43.21 \\
$\mathbf{4 g}$ & -3.69 & -69.62 \\
$\mathbf{4 i}$ & -3.65 & -71.43 \\
$\mathbf{4 l}$ & -3.61 & -65.21 \\
$\mathbf{4 a}$ & -3.59 & -61.30 \\
$\mathbf{4 c}$ & -3.46 & -68.71 \\
$\mathbf{4 n}$ & -3.44 & -62.80 \\
$\mathbf{4 k}$ & -3.27 & -55.61 \\
$\mathbf{4 h}$ & -2.59 & -67.47 \\
$\mathbf{4 d}$ & -2.46 & -64.18 \\
$\mathbf{4 m}$ & -2.13 & -62.32 \\
Gabapentin & $-\mathbf{2 . 5 1}$ & $\mathbf{- 4 0 . 2 4}$ \\
\hline
\end{tabular}

2D ligand interaction diagram of $\mathbf{4 e}$ was represented in Figure 1(a).
The most potent compound $\mathbf{4 e}$ fitted nicely into the hBCATc enzyme making five hydrogen bond interactions with the most important active site residues ARG 143(N.... HN), LYS 202 (O...HN), ALA 314 (O....HN), THR 313 $(\mathrm{O} . . . \mathrm{HN})$ and TYR 141 (O....HO) Figure 1(b). The PHE 75 residue makes pi-pi interaction with the $p$-nitro phenyl ring in compound 4e at distances $5.40 \AA$ (phenyl....phenyl). The $\mathrm{NH}$ of thiamide group in $\mathbf{4 b}$ seems to have an important role in strong hydrogen bond interaction with THR 240 (H...OH) as shown in Figure 2(b). Moreover compound 4b formed a pi-cation interaction with LYS 202 (Phenyl.... $\mathrm{H}_{3} \mathrm{~N}^{+}$). The current study showed that the presence of nitro group at para position of aromatic ring in $\mathbf{4 e}$ has significant activity and their docking scores. The polar regions in catalytic site was found near nitro group and surrounded by ARG 99, GLU 76, LYS 202 and GLY 77, which favours the interaction of nitro group leads to high docking score. A docking study of co-crystal ligand, gabapentin was performed which displayed a hydrogen bonding with the side chains of THR 240, TYR 141 and backbone of THR 313 and ALA 314, depicted in Figure 3(a). The 4e and gabapentin has almost same biding mode and both the compounds share some common hydrogen bond such as THR 313, ALA 314 and TYR 141. The receptor 

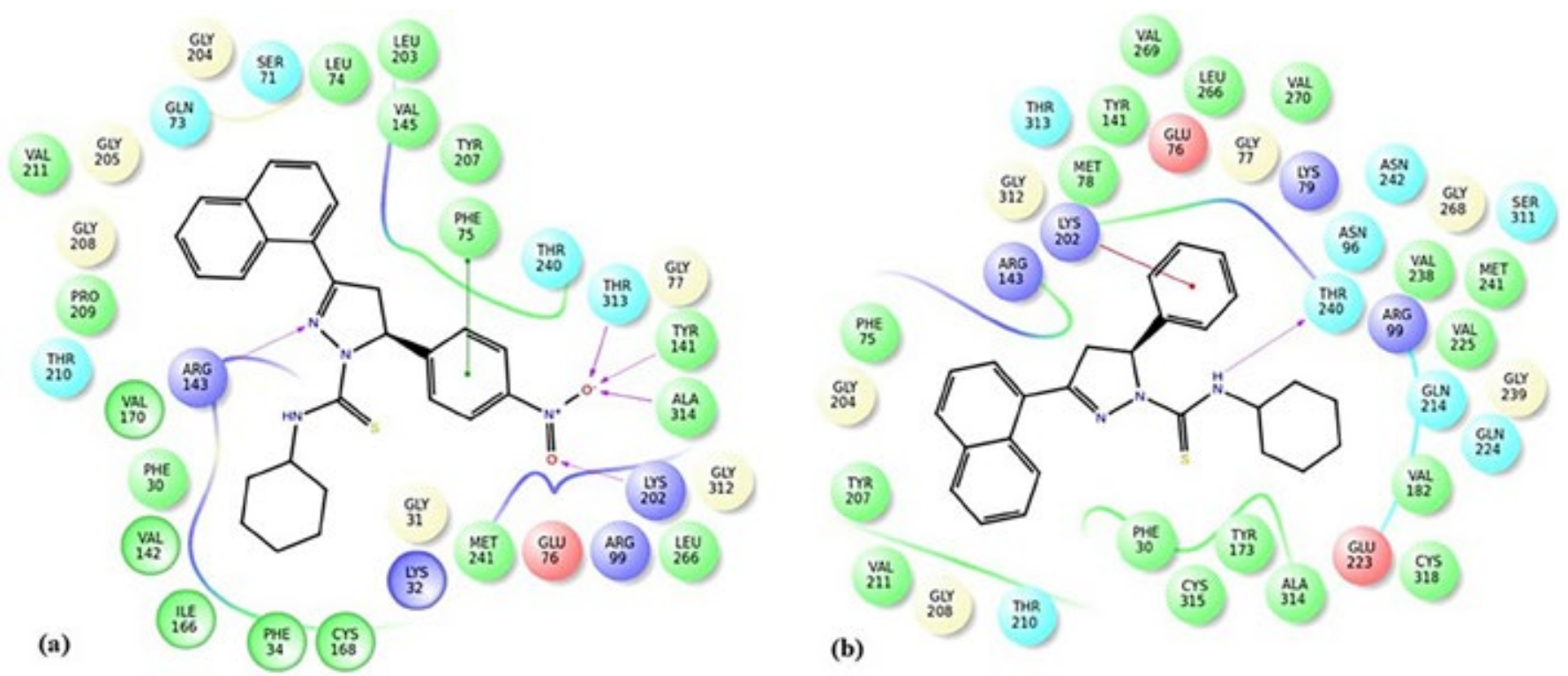

FIGURE 1 - 2D Ligand interaction of (a) compound $4 \mathrm{e}$ (b) compound $\mathbf{4 b}$, using LigPlot.

surface view of superimposed structure of gabapentin and $4 \mathbf{e}$ in the binding site are represented in Figure 3(b). The molecular docking protocol was validated by redocking of the co-crystallized ligand, gabapentin back into the same active site of hBCATc and found to have almost same interaction. The docking of co-crystal ligand, gabapentin against the generated grid showed almost same docking mode as compound 4e with RMSD value of 1.7 and therefore, docking protocol was validated by the generated grid.The molecular surface model of compound 4e is represented in Figure 2. The dG binding energy of compounds was found in the range of -43.21 to -71.43 $\mathrm{Kcal} / \mathrm{mol}$ for enzyme hBCATc active sites (Table III). All the compounds displayed a higher binding free energy (dG bind) for hBCATc which indicates that compounds have higher selectivity and stability towards hBCATc. Whereas, the binding energy of co-crystal ligand was found to be $-40.24 \mathrm{kcal} / \mathrm{mol}$ and less than the synthesized compounds (4a-n).
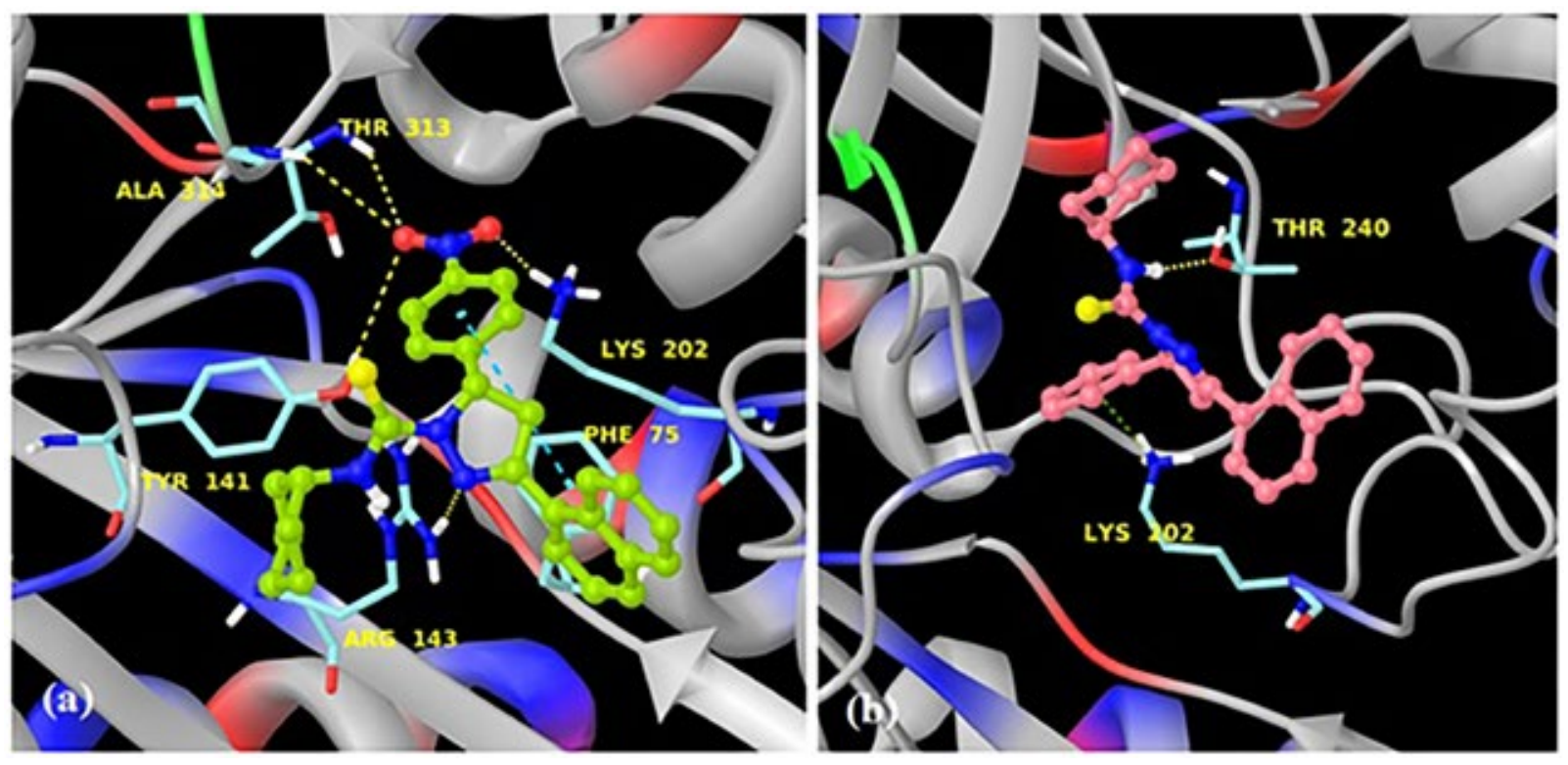

FIGURE 2 - (a) Docked pose of best ranked docking score of compound 4e (yellow green colour) represented as ball and stick in the binding site of hBCATc showing hydrogen bond interaction (yellow dash lines) (b) Docked pose of compound $\mathbf{4 b}$ (pink colour) represented as ball and stick in the binding site of hBCATc showing hydrogen bond interaction (yellow dash lines) and pi-cation interaction (green dash lines). 

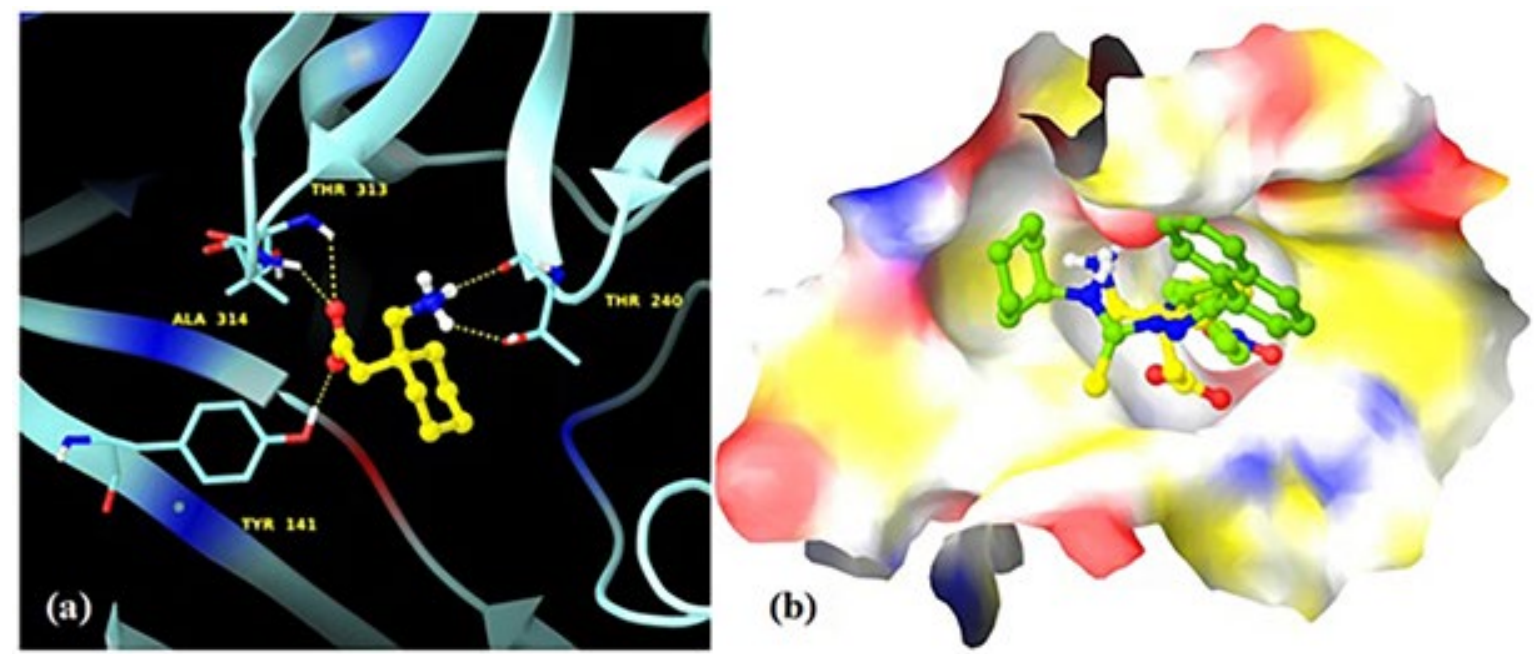

FIGURE 3 - (a) Docked Pose of co-crystal, gabapentin (yellow colour) represented as ball and stick in the binding site of hBCATc showing hydrogen bond interaction (yellow dash lines) (b) A receptor surface of superimpose gabapentin (yellow colour) with 4e (yellow green colour) in the binding site of hBCATc.

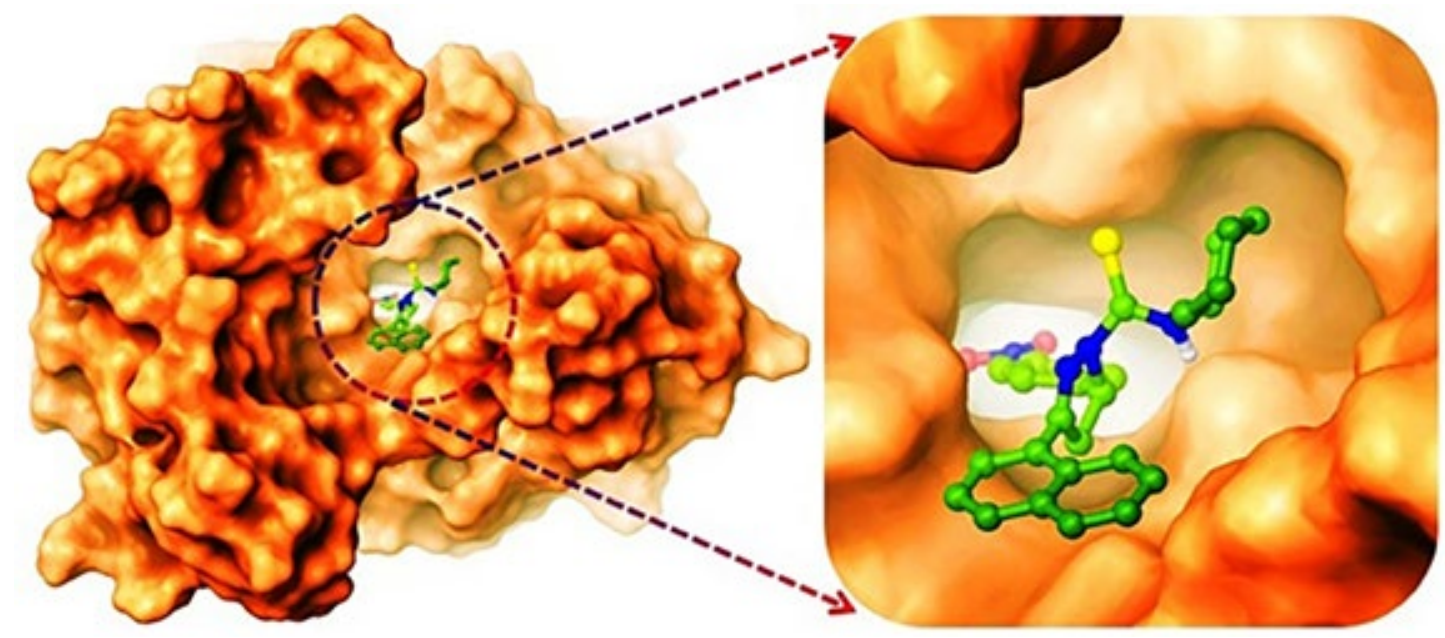

FIGURE 4 - Surface view of compound 4e. The protein is depicted in the surface view and ligand $\mathbf{4 e}$ as ball and stick in the binding pocket of hBCATc receptor.

\section{CONCLUSION}

In the present study, new 2-pyrazoline derivatives (4a-n) were synthesized and tested for their anticonvulsant potential against MES and scPTZ model. In MES model, compounds $\mathbf{4 g}, \mathbf{4 i}, \mathbf{4 j}$ and $\mathbf{4 n}$ were found most potent among all.Furthermore, in the scPTZ test, $\mathbf{4 e}$ and $\mathbf{4 l}$ were found to be most active at the lowest dose of $30 \mathrm{mg} / \mathrm{kg}$ which is comparable to standards carbamazepine and phenytoin. The molecular docking study of the compound $4 \mathbf{e}$ was also found in favor of biological activity. The molecular docking study was performed for the better understanding of drug-receptor interactions. Therefore, it can be used as a perspective pharmacophore model for the design and to illustrate potential activity. The above compounds can be considered as strong candidates for future investigations.

\section{CONFLICT OF INTEREST}

The authors declare no conflict of interest.

\section{ACKNOWLEDGEMENT}

The authors are thankful to School of Pharmaceutical Education and Research, Jamia Hamdard, New Delhi, India, for providing all necessary facilities for this work. The co-author (Dr. Ozair Alam) is thankful to DSTSERB (SB/FT/LS-203-2012), New Delhi, for providing molecular modelling software (Schrödinger, USA) under Fast track young scientist scheme. The authors are also thankful to Dr. Geetali Deori for providing the English certificate. 


\section{REFERENCES}

Beyhan N, Kaymakcioglu BK, Gümrü S. Aricioglu F. Synthesis and anticonvulsant activity of some 2-pyrazolines derived from chalcones. Arabian J Chem, 2017;10(2):S2073-S2081.

Desaubry L, Wermuth CG, Boehrer A, Marescaux C, Bourguignon J. Synthesis and anticonvulsant properties of BWA78U structurally-related compounds. Bioorg Med Chem Lett. 1995;5(2):139-44.

Dimmock JR, Pandeya S, Quail JW, Pugazhenthi U, Allen TM, Kao GY, et al. Evaluation of the semicarbazones, thiosemicarbazones and bis-carbohydrazones of some aryl alicyclic ketones for anticonvulsant and other biological properties. Eur J Med Chem. 1995;30:303-14.

Dimmock JR, Vashishtha SC, Stables JP. Anticonvulsant properties of various acetylhydrazones, oxamoylhydrazones and semicarbazones derived from aromatic and unsaturated carbonyl compounds. Eur J Med Chem. 2000;35(2):241-48.

Dunham NW, Miya TA, Edwards LD. The pharmacological activity of a series of basic esters of mono- and dialkylmalonic acids. J Am Pharm Assoc. 1957;46(1):64-6.

Furniss BS, Hannaford AJ, Smith PWG, Tatchell AR. Vogel's textbook of practical organic chemistry. Ed. Arthur Israel. $5^{\text {th }}$ ed.England:Addison Wesley Longman; 1998. p. 966-967.

Goto M, Miyahara I, Hirotsu K, Conway M, Yennawar N, Islam MM, Hutson SM. Structural determinants for branched-chain aminotransferase isozyme-specific inhibition by the anticonvulsant drug gabapentin. J Biol Chem. 2005;280(44):37246-56.

Hu LY, Boxer PA, Kesten SR, Lei HJ, Wustrow DJ, Moreland DW, et al. The design and synthesis of human branchedchain amino acid aminotransferase inhibitors for treatment of neurodegenerative diseases. Bioorg Med Chem Lett. 2006;16(9):2337-40.

Karad SC, Purohit VB, Thakor P, Thakkar VR, Raval DK. Novel morpholinoquinoline nucleus clubbed with pyrazoline scaffolds: Synthesis, antibacterial, antitubercular and antimalarial activities. Eur J Med Chem. 2016;112:270-79.
Krall RL, Penry JK, White BG, Kupferberg HJ, Swinyard EA. Antiepileptic drug development: II. Anticonvulsant drug screening.Epilepsia.1978;19(4):409-28.

Malik S, Bahare RS, Khan SA. Design, synthesis and anticonvulsant evaluation of $\mathrm{N}$-(benzo[d] thiazol-2ylcarbamoyl)-2-methyl-4-oxoquinazoline-3(4H)carbothioamide derivatives: A hybrid pharmacophore approach. Eur J Med Chem. 2013;67:1-13.

Miguel FB, Dantas JA, Amorim S, Andrade GFS, Costa LAS, Couri MRC. Synthesis, spectroscopic and computational characterization of the tautomerism of pyrazoline derivatives from chalcones. Spectrochim Acta A Mol Biomol Spectrosc. 2016;152:318-26.

Motyan G, Kovacs F, Wolfling J, Gyovai A, Zupko I, Frank E. Microwave-assisted stereoselective approach to novel steroidal ring D-fused 2-pyrazolines and an evaluation of their cellgrowth inhibitory effects in vitro. Steroids. 2016;112:36-46.

Schrodinger, Maestro, Version 10.1, LLC, New York, NY, 2016.

Stables JP, Kupferberg HJ. Chapter 16. The NIH Anticonvulsant Drug Development (ADD) Program: preclinical anticonvulsant screening project, Epilepsy Branch, National Institute of Neurological Disorders and Stroke, National Institutes of Health, Bethesda, MD 20892, USA; 1978.

Swinyard EA, Woodhead JH, White HS, Franklin MR. General principles: experimental selection, quantification, and evaluation of anticonvulsants. 3rd ed. In: Levy RH, Mattson RH, Melrum B, Penry JK, Dreifuss FE (editors).Antiepileptic drugs. New York:Raven-Press; 1989. p 85-102.

Thakur DS, Rajak H, Kumar P, Vaishnav Y. Synthesis of some novel 4-(4-chlorophenyl)-6-p-tolyl"pyrimidine derivatives and their anticonvulsant activity. Acta Pol Pharm. 2011;68(6):99397.

Received for publication on $23^{\text {rd }}$ December 2016 Accepted for publication on $20^{\text {th }}$ March 2018 